\title{
Growth and Yield Responses of Four Soybean (Glycine max (l.) Merrill.) Cultivars to Different Methods of NPK Fertilizer Application
}

\author{
DOI: 10.18196/pt.2020.112.39-43
}

\author{
Paul Benyamin Timotiwu*, Yayuk Nurmiaty, Eko Pramono, Siti Maysaroh \\ Department of Agrotechnology, Faculty of Agriculture, University of Lampung, Bandar Lampung, Lampung 35145, Indonesia \\ *Corresponding author, email: paul.timotiwu@fp.unila.ac.id
}

\begin{abstract}
This study aimed to determine the growth and yield responses of four soybean cultivars to different methods of N, P, and K fertilizers application. The methods consisted of one-time application (at the planting time) and split application (at the planting time and during the initial stage of pod formation (R3 stage)). Four superiors soybean cultivars were used, namely Anjasmoro, Grobogan, Dena-1, and Argomulyo. One-time fertilizers application resulted in an increased plant height compared to split fertilizers application. In contrast, the split fertilizers application led to a higher yield of soybeans indicated by the higher total number of pods, number of filled pods, 100-grain weight, and seed dry weight. CV. Anjasmoro produced higher growth and yield than cV. Grobogan, Dena-1, and Argomulyo. It also produced the highest yield compared to other cultivars. Meanwhile, cv. Argomulyo produced the lowest yield in both fertilization methods. Based on the soil analysis after harvest, the nutrient content of $K$ in the soil was higher than before planting in both fertilization methods. In addition, the split fertilizers application led to higher utilization of $P$ in the soil after harvest.
\end{abstract}

Keywords: Fertilization; Generative; Soybeans; Vegetative

ABSTRAK

Penelitian ini bertujuan untuk mengetahui tanggapan pertumbuhan dan hasil empat varietas kedelai terhadap cara pemberian kombinasi pupuk N, P, dan K. Cara pemberian kombinasi pupuk N, P, K satu kali saat awal vegetatif dan dua kali yaitu saat awal vegetatif dan fase awal berpolong (R3) diaplikasikan pada empat varietas unggul kedelai yaitu Anjasmoro, Grobogan, Dena-1, dan Argomulyo. Cara pemberian pupuk satu kali menghasilkan pertumbuhan tinggi tanaman yang diukur saat R3 lebih tinggi daripada cara pemberian dua kali sedangkan cara pemberian pupuk dua kali hasil kedelai lebih tinggi daripada cara satu kali. Hasil kedelai ditunjukkan oleh jumlah polong total, jumlah polong isi, bobot 100 butir, dan bobot kering biji. Varietas Anjasmoro menghasilkan pertumbuhan dan hasil lebih tinggi daripada varietas Grobogan, Dena-1, dan Argomulyo. Varietas Anjasmoro menghasilkan hasil tertinggi daripada varietas lainnya (Grobogan, Dena-1, dan Argomulyo) sedangkan varietas Argomulyo menghasilkan hasil kedelai terendah pada kedua cara pemupukan yang diterapkan. Informasi tambahan dari penelitian ini yaitu analisis tanah yang menunjukkan bahwa kandungan unsur hara K di dalam tanah setelah panen ternyata lebih tinggi daripada sebelum tanam. Unsur P di dalam tanah setelah panen terjadi penurunan lebih besar pada cara pemberian pupuk satu kali dibandingkan cara dua kali.

Kata Kunci: Pemupukan; Kedelai; Vegetatif; Generatif

\section{INTRODUCTION}

Soybean (Glycine max (L.) Merrill) is an agricultural commodity which is widely used, among others as processed food, raw industry material and as refreshment material. It is necessary to increase the soybean production every year as the number of population and industrial developments requiring raw materials of soybean keep increasing. The increase in soybean demand, which has fluctuated in the past five years and tends to increase by $2.49 \%$, is not balanced with the increase in soybean production which only increased by $0.86 \%$, from 954,997 tons/ha in 2014 to 963,183 tons/ha in 2015 (Central Bureau of Statistics, 2015). Therefore, various

efforts are required to increase soybean production, one of which is through fertilization.

According to Permanasari (2014), the effective use of fertilizers must fulfil the right five aspects, namely dose, type, time, method of administration, and target. Appropriate dose and proper fertilization method can optimize plant growth and yield thus increasing crop production. The results of the research on soybean responsiveness to N, P, and $\mathrm{K}$ fertilizers have so far not been consistent, in aspect of both the doses and the time of administration. $\mathrm{N}, \mathrm{P}$, and $\mathrm{K}$ fertilizers in soybeans are commonly administered once, which is at planting time. In 
this method, soybean production, especially at the level of farmer is still relatively low. The average national soybean productivity is 1.3 tons/ha ranging from 0.6 to 2.0 tons/ha, while at the research level, it reaches 1.7 -3.2 tons/ha, depending on the condition of the land and the technology applied (Edison et al., 2013). Soybeans production is still relatively low despite being given $\mathrm{N}, \mathrm{P}$, and $\mathrm{K}$ at the recommended doses.

The selection of cultivar, as one of the genetic factors that interacts with the environment, plays an important role in maximizing crop yields. It is stated that internal factors in genetic control vary from one cultivar to another cultivar so that a cultivar suitable for a particular condition is not necessarily suitable for other agro-climate conditions. In addition, each cultivar also has different responses to external factors, such as fertilization. The results of the research conducted by Marliah (2012) reported that cv. Anjasmoro and Grobogan produced higher plant height and seed weight per plant compared to cv. Kipas Merah. Different soybean cultivars gave different responses to the application method of N, P and K fertilizers. Therefore, the aim of this research was to find out the effectiveness of $\mathrm{N}, \mathrm{P}$, and $\mathrm{K}$ fertilizer application method in improving the growth and yield of soybeans.

\section{MATERIALS AND METHOD}

The research was conducted from February 2017 to June 2017 at the Integrated Field Laboratory (Gedong Meneng Campus, Bandar Lampung) and Laboratory of Seed and Plant Breeding, Faculty of Agriculture, University of Lampung. The treatments were arranged in factorial $(2 \times 4)$ randomized complete block design (RCBD) with 3 replications. Grouping was conducted based on planting days, which is 3 days apart.
The first factor was the method of NPK fertilizers application, namely one-time application (P1) at the beginning of vegetative growth and split application (P2) at the vegetative phase and the initial stage of pod formation. The second factor was soybean cultivars consisting of four soybean cultivars, namely Anjasmoro (v1), Grobogan (v2), Dena 1 (v3), and Agromulyo (v4).

The doses of fertilization in this study were 50 $\mathrm{kg} / \mathrm{ha}$ urea, $100 \mathrm{~kg}$ TSP and $100 \mathrm{~kg} / \mathrm{ha} \mathrm{KCl}$ for both application methods. The entire fertilizers in one-time application (p1) were given one week after planting except TSP which was given one week before planting. Meanwhile, the entire doses of fertilzers in split application were divided into two parts. The first half doses were $25 \mathrm{~kg} /$ ha urea, 50 $\mathrm{kg} / \mathrm{ha}$ TSP and $50 \mathrm{~kg} / \mathrm{ha} \mathrm{KCl}$ which were given one week after planting except TSP which was given one week before planting. The other half doses were $25 \mathrm{~kg} / \mathrm{ha}$ of urea, $50 \mathrm{~kg} / \mathrm{ha}$ of TSP and $50 \mathrm{~kg} / \mathrm{ha}$ of $\mathrm{KCl}$ which were given in the initial generative phase, which is initial stage of pod formation (R3) or about 7 weeks after planting.

Observations in this study include observing plant growth and production. Variables observed were plant height $(\mathrm{cm})$, plant dry weight $(\mathrm{g})$, total number of pods (pods), number of filled pods (pods), and weight of 100 grains (g). All data were analyzed by Least Significant Difference (LSD) at a 0.05 (5\%).

\section{RESULTS AND DISCUSSION}

Soybean Production as Affected by Cultivars and Different Methods of NPK Fertilizers Application

There was interaction effect between soybean cultivars and the method of NPK fertilizers application on the number of filled pods and dry weight of seed ( $t / h a)$. Both application methods on Anjasmoro resulted in higher number of total pods and dry weight of seeds (ton/ha) (Table 1 and 2). 
Affected by one-time application, cv. Anjasmoro produced the highest number of filled pods and dry weight of seed, followed by cv. Grobogan, Dena-1, and Argomulyo, respectively. Likewise, in split application, cv. Anjasmoro also showed the highest number of filled pods and dry weight of seeds, followed by cv Grobogan and Dena-1, and the lowest yield was observed in cv. Argomulyo. However, according to the average effects of the fertilization methods on the four cultivars, it can be seen the split fertilizers application gave a better result.

Table 1. Number of filled pods as affected by soybean cultivars and different methods of NPK fertilizers application

\begin{tabular}{lcccc}
\hline \multirow{2}{*}{$\begin{array}{l}\text { Fertilizers } \\
\text { Application }\end{array}$} & \multicolumn{4}{c}{ Cultivar } \\
\cline { 2 - 5 } & Anjasmoro & Grobogan & Dena-1 & Argomulyo \\
\hline One-time (P1) & $74,17 \mathrm{a}$ & $63,50 \mathrm{~b}$ & $64.67 \mathrm{~b}$ & $62.83 \mathrm{~b}$ \\
& $\mathrm{~B}$ & $\mathrm{~B}$ & $\mathrm{~A}$ & $\mathrm{~A}$ \\
Split (P2) & $89.00 \mathrm{a}$ & $74.00 \mathrm{~b}$ & $70,00 \mathrm{bc}$ & $66.50 \mathrm{C}$ \\
& $\mathrm{A}$ & $\mathrm{A}$ & $\mathrm{A}$ & $\mathrm{A}$ \\
\hline
\end{tabular}

Remarks: Means followed by the same letters, uppercase letters for cultivars and lowercase letters for fertilization methods, are not significantly different based on the 5\% LSD Test $=5.74$.

Table 2. Dry weight of seeds as affected by soybean cultivars and different methods of NPK fertilizers application

\begin{tabular}{lcccc}
\hline \multirow{2}{*}{$\begin{array}{l}\text { Fertilizers } \\
\text { Application }\end{array}$} & \multicolumn{4}{c}{ Cultivar } \\
\cline { 2 - 5 } & Anjasmoro & Grobogan & Dena-1 & Argomulyo \\
\hline One-time (P1) & $1.25 \mathrm{a}$ & $1.06 \mathrm{~b}$ & $1.03 \mathrm{~b}$ & $1.00 \mathrm{~b}$ \\
& $\mathrm{~B}$ & $\mathrm{~B}$ & $\mathrm{~B}$ & $\mathrm{~A}$ \\
Split (P2) & $2.33 \mathrm{a}$ & $1.73 \mathrm{~b}$ & $1.55 \mathrm{c}$ & $1.11 \mathrm{c}$ \\
& $\mathrm{A}$ & $\mathrm{A}$ & $\mathrm{A}$ & $\mathrm{A}$ \\
\hline
\end{tabular}

Remarks: Means followed by the same letters, uppercase letters for cultivars and lowercase letters for fertilization methods, are not significantly different based on the 5\% LSD Test $=0.19$.

Growth and Yield Responses of Soybean Cultivars to the Different Methods of NPK Fertilizers Application

One-time fertilizers application produced better plant growth than split fertilizers application as indicated by the plant height. NPK fertilizers application at initial growth phase will affect the availability of assimilates during vegetative growth of the plants. One-time fertilizers application at the initial growth phase was thought to provide more $\mathrm{N}$, P, and $\mathrm{K}$ nutrients which were needed in this phase compared to the split fertilization (Table 3). This is in line with Jamili's study (2017) reporting that the application of $50 \mathrm{~kg} / \mathrm{ha}$ of Urea, $100 \mathrm{~kg} / \mathrm{ha}$ of TSP, and $100 \mathrm{~kg} / \mathrm{ha}$ of $\mathrm{KCl}$ resulted in a higher growth rate of soybean compared to the application of $25 \mathrm{~kg} / \mathrm{ha}$ of Urea, $100 \mathrm{~kg} / \mathrm{ha}$ of TSP, and 100 $\mathrm{kg} / \mathrm{ha}$ of $\mathrm{KCl}$.

Table 3. Soybean Growth and Yield Response to different methods of NPK fertilizers application

\begin{tabular}{|c|c|c|c|}
\hline \multirow{2}{*}{ Observation variables } & \multicolumn{2}{|c|}{ Fertilizers Application } & \multirow[t]{2}{*}{$5 \%$ LSD } \\
\hline & One-time (P1) & Split (P2) & \\
\hline $\begin{array}{l}\text { Plant height } 5 \text { weeks after } \\
\text { planting }(\mathrm{cm})\end{array}$ & $35.75 \mathrm{a}$ & $33.54 b$ & 2.01 \\
\hline Total number of pods & $72.46 b$ & $78.42 \mathrm{a}$ & 2.97 \\
\hline 100 grain weight & $14.64 \mathrm{~b}$ & $16.84 \mathrm{a}$ & 1.58 \\
\hline
\end{tabular}

Remarks: Means followed by the same letters are not significantly different based on the $5 \%$ LSD Test.

Nevertheless, the split fertilization obtained highr yields than the one-time fertilization as indicated from higher number of total pods, number of filled pods, 100 grain weight, and dry weight of seed ( $t /$ ha) (Table 3). This is presumably because the nutrients needed by plants for yielding are still available due to the second fertilizer application. Nutrients given in the generative phase (initial pod forming) could increase the metabolic process for optimizing the seed production due to the availability of assimilates during maximum seed filling. This result is in line with Tabri's research (2010) reporting that $\mathrm{N}, \mathrm{P}$, and $\mathrm{K}$ fertilizers application produced the highest weight of 100 grains (g) and the highest seed yield ( $t / h a)$ followed by the provision of NK (-P), NP (-K), and PK (-N) fertilizers. This shows that $\mathrm{N}$ is needed in the generative phase. The rsults of Saragih's study (2013) revealed that split Urea application at a dose of $100 \mathrm{~kg} / \mathrm{ha}$ (at a week after planting and early flowering) increased corn yield by 10.65 t/ha. According to Saragih (2013), nitrogen is absorbed by plants during the growing period until the maturation of seeds so that the plant requires continuous $\mathrm{N}$ availability in all growth stages until seed formation. 
Table 4. Growth and production responses of different soybean cultivars

\begin{tabular}{lccccc}
\hline \multirow{2}{*}{ Observation variables } & \multicolumn{2}{c}{ Cultivars } & \multicolumn{2}{c}{$5 \%$ LSD } \\
\cline { 2 - 6 } & Anjasmoro & Grobogan & Dena-1 & Argomulyo \\
\hline Plant height 5 weeks after planting $(\mathrm{cm})$ & $36.52 \mathrm{a}$ & $32.27 \mathrm{~b}$ & $33.03 \mathrm{~b}$ & $36.11 \mathrm{a}$ & 3.01 \\
Stunted dry weight $(\mathrm{g})$ & $8.67 \mathrm{a}$ & $4.87 \mathrm{c}$ & $8.05 \mathrm{ab}$ & $7.05 \mathrm{~b}$ & 1.48 \\
Total number of pods & $84.67 \mathrm{a}$ & $75,58 \mathrm{ab}$ & $72.75 \mathrm{bc}$ & $68.75 \mathrm{c}$ & 4.20 \\
100 grain weight & $17.86 \mathrm{a}$ & $15.24 \mathrm{~b}$ & $15.79 \mathrm{~b}$ & $14.08 \mathrm{~b}$ & 2.24 \\
\hline
\end{tabular}

Remarks: Means followed by the same letters are not significantly different based on the 5\% LSD Test.

Growth and Yield Responses of Different Soybeans which initially was $317.18 \mu \mathrm{g} / \mathrm{g}$, decreased after Cultivars. harvest. The one-time fertilization resulted in $\mathrm{P}$

Cv. Anjasmoro showed higher growth and yield than other cultivars, indicated on higher plant height and dry weight (Table 4). According to Research Institute for Peanuts and Tubers (2017), cv. Anjasmoro can grow up reaching 64-68 $\mathrm{cm}$. Ratnasari's research (2015) reported that cv. Anjasmoro produced the highest plant height at 6 weeks after planting compared to cv. Grobogan. The high growth rate of $\mathrm{cv}$. Anjasmoro in a better production rate as well as on dry weight, total pods, number of filled pods, weight of 100 seeds and dry weight of seeds ( $t / h a)$. The difference in characteristics between the four cultivars used can also influence soybean growth and yield. Each cultivar has its own advantages. Zahrah (2011) states that soybean plants have many varieties, each variety will give different responses to growth and production rate. Each variety has genetic characteristics that are not the same, which can be seen from the phenotype and characteristics of each of these varieties. According to Melati et al. (2008), the diversity of soybean seed size in one variety occurs due to the diversity of conditions between plants in the crop, and the diversity of plant conditions so that the weight of soybean seeds is influenced by the size of plant seeds that are influenced by genetic and environmental factors. content of $231.15 \mu \mathrm{g} / \mathrm{g}$, while the split fertilization resulted in P content of $278.28 \mu \mathrm{g} / \mathrm{g}$. Thus, it was concluded that the soybean plants took available P nutrients in the soil and took part of the P from the added fertilizers.

Table 5. Results of soil analysis before planting

\begin{tabular}{llll}
\hline No. & Parameter & Unit & Results \\
\hline 1 & $\mathrm{P}$ & $\mu \mathrm{g} /$ gdry base & 317.18 \\
2 & $\mathrm{~K}$ & $\mu \mathrm{g} /$ gdry base & 278.60 \\
3 & $\mathrm{~B}$ & $\mu \mathrm{g} /$ gdry base & 36.67 \\
4 & $\mathrm{Ca}$ & $\mu \mathrm{g} /$ gdry base & 2095.07 \\
5 & $\mathrm{Na}$ & $\mu \mathrm{g} /$ gdry base & 131.99 \\
6 & $\mathrm{Fe}$ & $\mu \mathrm{g} / \mathrm{gdry}$ base & 56164.25 \\
7 & $\mathrm{Zn}$ & $\mu \mathrm{g} /$ gdry base & 44.86 \\
8 & $\mathrm{Cu}$ & $\mu \mathrm{g} /$ gdry base & 9.90 \\
9 & $\mathrm{pH}$ & - & 6.04 \\
10 & $\mathrm{PO}_{4}^{-3}$ & $\mu \mathrm{g} /$ gdry base & 636 \\
\hline
\end{tabular}

Table 6. Results of soil analysis after planting and fertilizers application

\begin{tabular}{lllll}
\hline $\begin{array}{l}\text { Sample name / } \\
\text { sample code }\end{array}$ & $\begin{array}{c}\text { Test } \\
\text { parameters }\end{array}$ & Unit & Results & Test method \\
\hline Split fertilized & $\mathrm{N}$ & $\% \mathrm{w} / \mathrm{w}$ & 0.27 & AOAC 2001.1 \\
soil / 019/ TNBT & $\mathrm{P}$ & $\mu \mathrm{g} / \mathrm{g}$ & 278.28 & Inhouse Method \\
$/ 12 / \mathrm{BL} / 12 / 17$ & $\mathrm{~K}$ & $\mu \mathrm{g} / \mathrm{g}$ & 873.18 & Inhouse Method \\
& $\mathrm{K}$ & $\% \mathrm{w} / \mathrm{w}$ & 0.22 & AOAC 2001.1 \\
One-time & $\mathrm{N}$ & $\mu \mathrm{g} / \mathrm{g}$ & 231.15 & Inhouse Method \\
fertilized soil/ & $\mathrm{P}$ & $\mu \mathrm{g} / \mathrm{g}$ & 539.57 & Inhouse Method \\
020/ TNBT/12 & $\mathrm{F}$ & & & \\
/ BL/12/17 & $\mathrm{K}$ & &
\end{tabular}

Absorption of $\mathrm{K}$ nutrients by soybean plants only takes up little $\mathrm{K}$ nutrients that have been added to the soil. The results of soil analysis after harvest showed that there was an increase in $\mathrm{K}$ elements in the soil, which increased from 278.60

The results of soil analysis before planting and after harvest showed that $\mathrm{P}$ nutrients in the soil, 
$\mu \mathrm{g} / \mathrm{g}$ to $539.57 \mu \mathrm{g} / \mathrm{g}$ in one-time fertilizers application and $873.18 \mu \mathrm{g} / \mathrm{g}$ in split fertilizers application (Table 5 and 6). this possibility caused the presence of $\mathrm{Na}$ in soil could replaces $\mathrm{K}$ (Marschner and Cakmak, 1989). Based on these results, it was concluded that the split fertilizers application was efficient because the absorption of the nutrients was less than the one-time fertilizers application.

\section{CONCLUSION}

One-time NPK fertilizers application produced better growth than the split fertilization as indicated on plant height. However, the split fertilizers application resulted in higher yields of soybeans by producing higher number of total pods, number of filled pods, weight of 100 grains, and dry weight of seeds. Cv. Anjasmoro produced higher growth and yield than cv. Grobogan, Dena-1, and Argomulyo. Both fertilizers application methods on cv. Anjasmoro produced the highest yield compared to other cultivars. Cv. Anjasmoro and Grobogan produced the highest yields if treated with split fertilizers application, while cv. Dena-1 and Argomulyo did not show different responses to either one-time or two times. Based on the results of soil analysis, the $\mathrm{K}$ content after harvest, higher than before planting, while the $\mathrm{P}$ content was higher in split fertilizers application.

\section{REFERENCES}

Central Bureau of Statistics. (2015). Soybean Production in Indonesia. http://www.bps.go.id

Research Institute for Peanuts and Tubes. (2017). Description of Soybean Varieties. http: //balitkabi.litbang.deptan.go id / images / PDF / description_kedelai.pdf

Edison, Denny D, and DS Nurchaini. (2013). Development Model of Soybean Seed Production in Dry Land in Tebo Regency. Jambi

Epstein, E. and Bloom, A. (2005). Mineral nutrition of plants principles and perspectives, 2 nd Edition. Sinauer Associates Inc. Publisher. pp. 400

Jamili, MJ, Jurnawaty. S., and Al Ikhsan. A. (2017). The Effect of Rice Straw and the Ratio of Urea, Tsp, Kcl to Soybean Growth and Production (Glycine max (L) Merril.). Jom Faperta, 4 (1): 1-15. https://jom.unri.ac.id/index.php/JOMFAPERTA/article/ view/16778
Marliah, A. (2012). Effect of Varieties and Plant Spacing on Soybean Growth (Glycine max (L.) Merrill). Agrista Journal, 16 (1): 1-28. http://www.jurnal.unsyiah.ac.id/agrista/article/view/679

Marschner, H. and Cakmak, I. (1989). High light intensity enhances chlorosis and necrosis in leaves of zinc, potassium, and magnesium deficient bean (Phaseolus vulgaris) plants. J. Physiol Plant. 134, 308-315

Melati, M., Ai Asiah and Dewi R. (2008). Application of Organic Fertilizers and Residues for the Production of Young Harvest Soybean. IPB Research Center. Bogor. Agronomic Bulletin, 36 (3): 204-213. http://repository.ipb.ac.id/handle/123456789/35770

Permanasari, I and Irfan, M. (2014). Growth and Yield of Soybeans (Glycine Max (L.) Merill) By Giving Rhizobium and Urea Fertilizers on Peat Media. Journal of Agrotechnology . 5 (1): 29 - 34. http://ejournal.uin-suska.ac.id/index.php/agroteknologi/article/ view/1145

Ratnasari, D., Bangun, M. K., dan Damanik, R. I. M. (2015). Respons Dua Varietas Kedelai (Glycine max (L.) Merrill.) pada Pemberian Pupuk Hayati dan NPK Majemuk. Jurnal Online Agroekoteknologi, 3 (1): 276 - 282 Desember 2015.

Saragih, D., H. Hamim, and Nurmauli, N. (2013). Effect of Dosage and Time of Application of Urea Fertilizers in Increasing Growth and Yield of Corn (Zea mays, L.) Pioneer 27. J. Tropical Agriculture, 1 (1): 50-54. http://jurnal.fp.unila.ac.id/index.php/ JA/article/view/1890

Tabri, Fahdiana. (2010). Effect of N, P, K Fertilizers on Growth and Hybrid Corn and Composite Results on Endoaquestlnsepticol Soil Barru Regency, South Sulawesi. Proceedings of the National Cereal Week. Cereal Crop Research Institute.

Zahrah, S. (2011). The response of various soybean varieties (Glycine $\max (L$.$) Merril) to the provision of Organic NPK fertilizer.$ J. Teknobiol, 2 (1): 65-69. https://ejournal.unri.ac.id/index.php/ JTB/article/view/1403/1390 